\title{
Afghanistan's arrested development: combating Taliban resurgence with an eye for lasting peace
}

\author{
Allison M Coady* and Hussein Solomon \\ Department of Political Sciences, University of Pretoria, Pretoria, South Africa
}

\begin{abstract}
Nearly eight years have passed since the Taliban were decisively removed from power, yet so far the international community together with the Afghan government lack a common and successful strategy necessary for the stabilization of the country. In this time, the Taliban have taken advantage of an environment of confusion and disjointed efforts to regroup and are currently making significant ground towards regaining control of Afghanistan. Success was never guaranteed in Afghanistan, nor was failure inevitable; but it is not the time to scale back efforts aimed at attaining durable peace, security and good governance for the Afghan people. It is imperative that coalition partners rethink their approach to Afghanistan and adopt a new, comprehensive strategy to avert disaster. Key to such a strategy must be the eradication of the root causes that led to the Taliban's first rise to power.
\end{abstract}

Keywords: Afghanistan; Taliban; NATO; Pakistan; insurgency; terrorism; religious fundamentalism

\section{Introduction}

Hope for a positive future in Afghanistan is not lost. That said, any progress made since the ousting of the Taliban rule seven years ago is under serious threat. When examining the current crisis in Afghanistan, which includes the significant resurgence of the Taliban, observers must understand that the situation is tremendously complex; an overarching solution will not easily be found. International policy makers continue to make the same mistake of approaching conflicts in a conventional, narrow-minded and incoherent manner. They carry with them a number of restricting attitudes, perceptions and expectations that inhibit the conflict resolution process. The Bonn Agreement is a good example.

In December 2001, representatives of various Afghan factions, including military commanders, representatives from different ethnic groups, and expatriate Afghans met in Bonn, Germany, under the patronage of the United Nations to decide the future of Afghanistan following the routing of the Taliban from power. The initial and naïve expectation of the international community (mainly the United States) was that 'the responsibility for providing security and law and order throughout the country resides with the Afghans themselves'. ${ }^{1}$ Despite the fact that the US-led military assault to oust the Taliban from power only two months earlier had left the country in absolute disarray, the United States insisted on pressuring the Bonn participants to swiftly reach an agreement. The brief final product consisted of idealistic goals, unrealistic timelines and a lack of key provisions, such as formal commitments by Afghanistan's neighbours (i.e. Pakistan) to

*Corresponding author. Email: acoady@sacbc.co.za 
stop supporting military factions like the Taliban and to begin respecting the country's self-determination. ${ }^{2}$

The Bonn Agreement is remembered as a missed opportunity. Reporting only one year after the signing of this sub-standard agreement, Human Rights Watch observed that within months of the meeting in Bonn regional and local military commanders and warlords became more entrenched in power than during the Taliban rule and remained a major threat to Afghanistan's peace and security. ${ }^{3}$ More than eight years later, warlords continue to plague Afghanistan, and a plethora of serious impediments have developed across all thematic areas, both of which have allowed for a hazardous resurgence of the Taliban.

Policy makers can no longer approach the crisis in Afghanistan with linear and disunited strategies and actions. They must instead think outside the traditional box of conflict resolution and consider some central realities. Firstly, the safe havens offered to the insurgent leadership in Pakistan must be eliminated. Secondly, international forces on the ground and key actors committed to finding peace for Afghanistan must address the legitimate needs of the ordinary Afghan by shifting focus from the centralised national governance plan to the far-reaching local level. Thirdly, we must abandon hope of negotiating with the Taliban. If the 2004 attempt to negotiate with the Taliban at Musa Qala taught the international community any lesson, it would be that opening a dialogue process with violent extremists only allows the insurgents to regroup and strengthen their ability to unleash further fatal attacks on a society longing for peace. Fourthly, but not finally, a long-term commitment must be made (including manpower, sufficient funds and time) to build meaningful and accountable governmental, security, economic and social service institutions that relentlessly punish corruption and aim to protect, provide for and thus empower the people of Afghanistan.

It is the aim of this paper to provide policy makers with comprehensive recommendations and guide those key actors in the search for peace in Afghanistan away from the predictable, conventional and to-date ineffectual conflict resolution approaches, and toward more innovative and effectual measures. An overview of the Taliban's structural and ideological make-up will be presented as well as an examination of measures undertaken so far to address the crisis. In order to avoid misunderstanding the conflict in Afghanistan, and because all those involved in and affected by the current crisis are likely to react according to their responses to past conflict, a solid understanding of Afghanistan's history of conflict is imperative and will be explored in the next section.

\section{Background}

For centuries, Afghanistan has been in a state of recurrent conflict at the hands of foreign powers. This realisation must be at the forefront of analysts' minds when they ask themselves why Afghans today are increasingly losing confidence in an international presence and once again considering pledging their support to the insurgent Taliban forces. During the Cold War, the arid landlocked country featured as a hot playing field. Communist forces were first to grasp control through a coup by the Communist People's Democratic Party in the 1970s. Internal power struggles nearly led to the collapse of the Afghan Communist regime; thus, in 1979 the Soviets decisively invaded the country to ensure that Afghanistan remained red on the map of Cold War politics. The invasion marked the beginning of a long and destructive occupation that witnessed the deaths of more than ten million people. A conservative resistance emerged in response and gained momentum when actively backed by the US and neighbours Pakistan, Saudi Arabia and 
Iran. Finally in 1989, under tremendous pressure from the anti-Communist mujahadin rebels, the Soviets withdrew from Afghanistan.

The expulsion of the Soviet presence certainly did not promise Afghanistan a brighter future. The mujahadin alliance became irreparably torn by ethnic and power contentions, sending Afghanistan into civil war. Chaotic fighting heavily targeted the civilian population in Kabul causing 40000 casualties and the destruction of the capital. ${ }^{4}$ The confused climate allowed for the emergence of the Taliban, a radical student movement that first materialised in the strict religious schools of Pakistan. With the powerful institutional sponsorship of Pakistan's security services, the Taliban, comprised almost entirely of ethnic Pashtun members led by Mullah Mohammed Omar, rapidly seized control of the southern city of Kandahar in 1994, Kabul in 1996, and the final major city in the north, Mazar-e Sharif in 1998. ${ }^{5}$ Although the fundamentalist regime controlled all but one remote area in the north east, only three countries, Pakistan, Saudi Arabia and the United Arab Emirates, recognised the Taliban as the legitimate government of Afghanistan.

The Taliban were further ostracised by the international community for refusing to hand over al-Qaeda leader Osama bin Laden, wanted for his role in the 1998 bombings of the American embassies in Kenya and Tanzania. ${ }^{6}$ Sanctions were imposed by the United Nations but did not jar the Taliban, who continued to allow al-Qaeda to operate freely within Afghanistan's borders. The terrorist attacks on New York and Washington, DC, on 11 September 2001 resulted in a quick and decisive military offensive led by the US, the Afghan Northern Alliance and coalition forces. The Taliban found itself ousted from power by early December of that year.

The story of the Taliban does not end here. Although many of its leaders and supporters were killed, captured, or forced into hiding, and despite the installation of a new democratic government in Kabul headed by President Hamid Karzai, the Taliban have regrouped. Relentless guerrilla attacks aimed at the NATO-led International Security Assistance Force (ISAF) and the American-led forces are causing significant casualties among soldiers and civilians. Funded by Afghanistan's notorious drug trade, the Taliban are growing stronger with every offensive.

\section{Inside the Taliban}

\section{Who are the Taliban?}

The Taliban ruled Afghanistan from 1996 to 2001, imposing Islamic fundamentalism and Pashtun nationalism. Their strict interpretation of Shar'ia law, especially the treatment of women, ostracised the Taliban from the international community. Although a joint military operation between Afghanistan's Northern Alliance and NATO forces ousted the Taliban from power in December 2001, recent years have witnessed a potent resurgence of the Taliban. The Karzai government has failed to exert its authority beyond Kabul and other urban centres, thus allowing the Taliban to regroup in the southern regions of the country in preparation of reasserting their own influence and control throughout Afghanistan.

Rise to power. During the Soviet occupation in 1979, seven Sunni Islamist parties operating out of Pakistan were given military and financial support by the US, its Western allies, and other Middle Eastern states such as Saudi Arabia. ${ }^{7}$ The parties were divided along strict ethnic lines and the Pashtun faction, known as the Taliban, received its greatest support from Pakistan because of the large numbers of influential Pashtun nationalists who occupy Pakistan's western borderlands. Millions of Afghan refugees streamed across the border into Pakistan during the civil war, providing the Pashtun group with an ideal recruitment 
pool. With funding and arms from America and unlimited support from Pakistan, the Taliban wielded tremendous clout, journeying back across the border to seize control of $90 \%$ of Afghanistan in less than four years. ${ }^{8}$

Taliban policies and ideology. The displaced and disillusioned Taliban youth were moulded by their country's history of violence and found solace and purpose in an extremely radical interpretation of Islam. Distorted versions of Sunni Deobandism and Pashtunwali, the tribal social code of the Pashtuns of Afghanistan and Pakistan, became the basis of the Taliban ideology. ${ }^{9}$ Once in power in Afghanistan, the authoritarian administration of the Taliban imposed their radical interpretations of Islam and Pashtun social codes as law. Non-Pashtun ethnic groups were suppressed, women's rights became non-existent, and no opposition to Taliban policies was tolerated.

In the beginning of their rule, the Taliban gained the support of a large percentage of the Afghan population, much to the shock of the rival factions. Exhausted from living a life of anarchy and corruption under the warlords or having their country host bloody wars as foreign powers vied for influence on the world stage, ordinary Afghans welcomed the new Taliban order that could provide them with relative stability. Under the leadership of Mullah Muhammad Omar, some of the corruption of the warlords was eliminated, the new penal code based on strict Shar'ia law was exceedingly — although brutally — efficient, and pathways were made for commerce to thrive. ${ }^{10}$ Under this strict Shar'ia law, public executions of convicted murderers and adulterers were regularly held in Afghanistan's soccer stadiums. Men were required to grow beards and would be subjected to public floggings if caught otherwise. The smallest of luxuries and the very basics of life's enjoyment for an ordinary Afghan were banned by the Taliban. As Amy Waldman notes in detail: ${ }^{11}$

\begin{abstract}
A kite seller will be imprisoned for three days. The owner of a house will be punished if women are heard singing during a wedding. No images or photographs are to be posted in public places. The following are considered 'unclean things': 'pork, pig, pig oil, anything made from human hair, satellite dishes, cinematography, any equipment that produces the joy of music, pool tables, chess, masks, alcohol, tapes, computer, VCRs, televisions, anything that propagates sex and is full of music, wine, lobster, nail polish, firecrackers, statues, sewing catalogues, pictures, Christmas cards'.
\end{abstract}

Thus, every activity, whether taking place in the public sphere or within the home, was strictly monitored and controlled by the 'religious police state' and it was women who bore the brunt of the Taliban's extremist laws.

Targeting Afghan women. Once the Taliban seized Kabul, their war on women's rights began with a vengeance. Girls over the age of eight were forbidden to attend school and working women were forced to remain in the home. ${ }^{12}$ One can imagine the drastic loss of capacity suffered by both the education and health systems in Afghanistan, where women more traditionally held professional positions. The compulsory wearing of the burqa in public spaces was not only a physical and psychological burden but an economic one, as many Afghan women could not afford the cost of the garment and had no choice but to share with their neighbours, thus being confined within the home for days. ${ }^{13}$ Women's participation in the Afghan economy was virtually eliminated, as they were prohibited from showing their hands during monetary exchange. Women were prohibited from leaving the home without the accompaniment of a male relative. In hospitals, women could only be medically examined when fully clothed, making an accurate diagnosis and treatment plan impossible. ${ }^{14}$ The Taliban perpetrated acts of rape, abduction and forced marriage all in the name of ensuring that Afghan women lived in security, dignity and honour. ${ }^{15}{ }^{16}$ Since the defeat of the Taliban, some progress has been made in improving the lives of women; 
however, the current Taliban resurgence presents a serious threat to the safety, security and protected rights of the women and girls of Afghanistan.

\section{A confident resurgence}

The Taliban may have been militarily and politically defeated in 2001, however the root causes that allowed for the Taliban's emergence in the first place are yet to be tackled. Similar trends to those that featured in 1994 are appearing during this current resurgence, and these must be carefully considered by the coalition forces. As discussed earlier, the initial acceptance and support of the Taliban's rule on the part of ordinary Afghan citizens was shocking to rival factions and to the outsider's eye. This very phenomenon is again occurring today as Afghans living outside the reach of the Karzai government feel the Taliban can provide better protection and governance.

In February 2008 a BBC film crew travelled to Kabul's neighbouring province of Wardak, where the Taliban operate freely and are supported by much of the local community. One villager interviewed expressed his confidence in the Taliban's concern for even the smallest of issues and stated, 'Even if it's a minor thing, the Taliban will sort it out. Before (when the government of President Karzai was in control) it was not like that. They did not pay attention to us and the poor people were ignored. ${ }^{17}$ The harsh exploitation of local farmers and villagers at the hands of warlords is rampant and if the ruling government cannot exert its control outside the capital to protect its citizens in the rural areas and the Taliban can offer an alternative form upholding a rule of law - or at least the perception thereof - there is no doubt that it is only a matter of time before the Taliban regain the support of an Afghan majority.

Adding a further layer of complexity to the situation is that fact that the Taliban are difficult to predict and to combat because they are not one homogenous group. There is confusion around the leadership structure and there are obvious tensions within the various factions. For example, in May 2008 pro-Taliban cleric, Mullah Fazlullah, and the Pakistan provincial government of Swat reached a peace pact where Taliban militants agreed to recognise the government's authority and halt attacks in exchange for the release of selected prisoners and government concessions on implementation of Islamic law. ${ }^{18}$ Some two months later, however, violence in the region once again erupted where security forces were attacked and girls' schools were set aflame, a direct rejection of the peace agreement. Other Taliban factions have no intention of ever negotiating and instead confidently launch manifestos and fatwas declaring 'The ruling to kill the Americans and their allies - civilians and military — is an individual duty for every Muslim who can do it in any country in which it is possible to. ${ }^{, 19}$ One thing is certain, the Taliban resurgence derives its direction from the south; instructions delivered to Taliban groups scattered across the country come from Kandahar, which must become a focal point for the foreign forces. If it is true that the Taliban are controlling areas such as Wardak then a new strategy in engagement in Afghanistan must immediately come into effect.

Other underlying conditions fuelling the current Taliban resurgence include Pakistan's continuing support, the Bush administration's shift in focus from Afghanistan to Iraq, an Afghan economy entirely based on opium production, the corruption embedded in the Karzai government and the failure to attain development and restructuring goals. Compounded by an intensifying propaganda campaign, these conditions are turning the support of ordinary Afghans away from what is seemingly becoming another international occupation of their country, back to the Taliban, a restricting yet perhaps more stable and united alternative. 
Pakistan, the ever-present ally. Pakistan's underlying support of the Taliban remains a key element in the current resurgence. Although President Musharraf committed his military to the American-led War on Terror, the Taliban retreated freely across the border and regrouped in the Pashtun-dominated territories of Pakistan. The Pakistani military government heavily relied on the mullahs to neutralise the moderate, democratic opposition, thus further empowering the Taliban. ${ }^{20}$ Furthermore, the two Pashtun dominated provinces in Pakistan are controlled by a six-party religious alliance, the Muttahida Majlis-i-Amal (MMA), composed mainly of Jamiat Ulema-e-Islam, the Taliban's early inspiration, and will therefore always provide the Taliban with a safe haven and a base of operations. ${ }^{21}$

Pakistan's involvement in the Taliban resurgence has a direct correlation to the $40 \%$ increase in insurgent attacks across Afghanistan since June last year. ${ }^{22}$ Almost one week after US government officials announced that the American death toll in Afghanistan in June was on par with the number of Americans deaths in Iraq during the same period of time, a deadly assault in the Konor province along the Pakistan border killed 9 American troops and wounded at least 15 US and 4 Afghan soldiers. ${ }^{23}$ Some NATO officials have explained the increase in attacks as a Taliban response to the rising numbers of foreign troops on the ground. However, others have suggested that the recent loss of ground by the coalition forces in the eastern provinces of Afghanistan indicate that there has been an increase in the number of Taliban insurgents fighting in the country. ${ }^{24}$ And where is this influx in manpower coming from? Where else but from the sanctuaries in bordering Pakistan?

Throughout 2008 Afghanistan and Pakistan have engaged in heated public arguments due to the Karzai government's suspicions that Pakistan's Inter-Service Intelligence agency (ISI) is actively aiding the Taliban insurgency. Negotiations have broken down and a written statement from Afghanistan's council of cabinet ministers declared, 'The people of Afghanistan and the international community have come to the reality that Pakistan intelligence institutions and its army have become the largest centre for breeding and exporting terrorism and extremism to the world and particularly to Afghanistan. ${ }^{25}$ This being said, it is also critical to recognise that the upcoming change in the Pakistani government will bring both challenges and exciting opportunities for Afghanistan's engagement with its neighbour to the east.

A drug-based economy. As outlined by the United Nations Development Programme (UNDP) in 2007, Afghanistan's economy is more dependent on the production, refinement and export of opium than is any other economy in the world ${ }^{26}$ The drug-based economy does not bring profits to the ordinary Afghan citizen, nor does it enrich the poppy farmers. It instead fuels corruption at every level of the Afghan government and is taxed by the Taliban to fund their own insurgent activities. Reportedly, $100 \%$ of the poppy farmers in the southern regions of Afghanistan pay taxes to warlords and various factions of the Taliban, as do $72 \%$ in the western provinces. ${ }^{27}$ Of the total $\$ 3.1$ billion in revenue from opium cultivation in Afghanistan, only a mere $\$ 755$ million is seen by Afghan farmers who must then face the Taliban taxes. ${ }^{28}$ Attempting to attack this root cause of insurgency, the Afghanistan interim government officially banned poppy cultivation in 2003, but this law proved ineffective. Poppy cultivation only continued to grow and today Afghanistan produces $93 \%$ of the world's supply of opium. ${ }^{29}$

Karzai the Corrupt? The challenges of a floundering government. Corruption is a serious hazard to development as its effects mainly impact the poor; it reduces the quantity and quality of social services, hinders national economic growth and more generally slows 
reconstruction projects. Corruption in Afghanistan has undermined the legitimacy of the government and has caused the civilian population to increasingly distrust foreign presence and international efforts to rebuild the country. The World Bank has ranked Afghanistan in the second or third lowest percentile for the control of corruption. ${ }^{30}$ The judiciary is perceived to be the most corrupt institution in the state followed by the administrative branches of the Afghan government. The inability on the part of the ordinary Afghan citizen to trust in the courts and the government explains why many people are willing to take their concerns to a more local and accessible level of leadership. It is clear that the Taliban are gaining momentum and support at the local level due to the vast corruption in Afghanistan's state structures.

The failure of military, development and restructuring programmes. A reflection of the deteriorating security situation in Afghanistan can also be seen in the failure of international military, development and restructuring programmes. The failure can be attributed to two major blunders: firstly, inability of both international and Afghan forces to extend their influence far beyond the city limits of Kabul to all the provinces; and secondly, the severe lack of a coherent international co-operation strategy. The moment the Taliban were ousted from power, allied forces had already agreed that a strong, centralised government must sit in the capital. Extensive planning and resources were poured into the creation of an interim government and then, in 2004, into the running of general, democratic elections. However, drastically less preparation was made for the maintaining of that government and for the strengthening of government influence at the provincial level. For this reason, the Taliban are able to operate freely in the southern provinces as well as the eastern regions bordering Pakistan.

Over 60 different countries are contributing to the effort to deal with the ongoing crisis in Afghanistan in various capacities, whether through the military or through humanitarian development missions. To take the military effort as an example, the major programmes in the sector include the US-led Operation Enduring Freedom and the NATO-led International Security Assistance Force (ISAF). Because of the number of countries contributing and a lack of consistent and all-inclusive planning and reporting meetings, there is little commonality in the policies, expectations, reporting schemes and results among the various contributors. Through ISAF, under a UN mandate and NATO leadership, 40 nations contribute to five regional commands and 26 national-led Provincial Reconstruction Teams (PRTs). The criticism of this set up is that each country involved views the situation in Afghanistan differently depending on where they are based within Afghanistan. Germany, for example, is mainly based in Northern Afghanistan, and the UK in the Helmand province. Each nation is not only restricted to certain areas, but also limits the activities its troops can participate in. This means that the forces mandated to serve in regions of heavy fighting suffer more casualties and general risk (i.e. those from the US, UK and Canada).

In conclusion, these basic problems of nation-wide reach and international cooperation are mutually reinforcing. It may have been intended that the creation of PRTs would carry the influence and support of NATO to all regions of Afghanistan. But clearly, with the lack of integration among country contributions, the success of each PRT will vary from the next.

It is the aim of the next section to provide concrete policy recommendations that encompass all actors in the conflict and that tackle the root causes that lead to such low success rates. 


\section{Urgent actions: policy recommendations}

The following policy recommendations seek to raise the effectiveness of the international community's contributions to Afghanistan by strengthening and uniting their strategies and resources, which include reconciling national and institutional differences, engaging the people of Afghanistan and renewing commitments for the long-term.

\section{Regarding a long-term commitment}

- All donors must recognise that in order to bring durable peace to Afghanistan and the region, commitments to Afghanistan must be extended for the next 10 years or longer; they must not consider renewing mandates on an annual basis.

\section{Regarding the strengthening of international leadership}

- The United Nations, through UNAMA (UN Assistance Mission in Afghanistan), must be given more responsibility to manage international efforts with the emphasis on capacity-building at the local level.

- UNAMA must renew and commit to its mandate, emphasising increased focus on regional assistance and the establishment of regional UN offices.

- The UN must maintain the consistent delivery of adequate resources to areas of heavy conflict, which requires tight leadership and clear communication from regional head officials.

- The UN must improve its coordination with NATO-led ISAF, which will include more regular communication between the regional commands, the creation of liaison officer positions posted at both organisations, and increasing engagement and input at all levels of ISAF planning and training.

- The UN must emphasise accountability and organisation through the better utilisation of the Joint Coordination and Monitoring Board (JCMB).

- The JCMB must enforce the requirement that its members submit reports on assistance programmes regularly and timeously and impose strict penalties for the failure to do so.

- The JCMB must meet more regularly and include comprehensive updates and follow-up methods.

- NATO through ISAF must co-ordinate the harmonisation of PRT mandates and introduce mandatory reporting schedules, abandoning the current method of nationally-determined direction.

- In situations where the UN may be able to better provide assistance, PRTs must cooperate with UNAMA to ensure a smooth transition process.

\section{Regarding military policies}

- NATO must increase the number of troops and trainers and support them with the appropriate military resources and collective mandates.

- Military mission co-ordinators must be willing to use force whenever necessary to ensure the success of a proficient combat mission, targeting leaders of the insurgency to deliver security with the lowest number of casualties possible. 
- Individual governments should lift restrictions on existing troops so that the brunt of heavy conflict does not continuously fall on troops deployed in the east and the south, such as the American, British, Canadian and Dutch soldiers.

\section{Regarding development programmes}

- Donors must increase funding and tangible resources to development and reconstruction programmes and find ways of using funds more effectively at the local level.

- The initial plans, the progress and the results of development programmes must be well communicated to the local populations.

Regarding the shift from a national, central approach to the local, strategists must:

- strengthen the delivery of social services by building up provincial administration and utilising the police to protect, rather than hinder the security of, ordinary Afghan citizens;

- harmonise local governance and the service-delivery systems;

- utilise PRTs to engage Afghan citizens in local governance plans and programmes; and

- introduce 'good governance' training to all government officials at all levels of the administration.

\section{Regarding counter-narcotics policies, the Afghan government must:}

- reassess approaches to counter-narcotics and abandon ideas of legally banning the farming of poppies and eradicating poppy fields via aerial spraying techniques;

- approach counter-narcotics policies with an aim to use the cultivation of opium to benefit the economy of Afghanistan, emphasising the return of the profits to the ordinary farmer; and

- consider involving the major multinational pharmaceutical corporations in the development of opiates for medicinal purposes and include the corporations in the monitoring and planning of the cultivation, refining and exporting processes.

\section{Regarding Afghan civil law-building policies: NATO countries must:}

- reassess police training methods by abandoning the insufficient two-week training project and enforce long-term training programmes with regular and mandatory refresher courses;

- root out corruption by using the Afghanistan government as an example and clamp down on corruption among high level officials with severe penalties; and

- target corruption in the courts through the complete reform of the Judiciary.

\section{Regarding regional engagement the international community must:}

- critically reassess the relations within the region with particular emphasis on Pakistan; and 
- consider the implications of growing instability in neighbouring Pakistan and the growth of radical Islamism there, together with the close relationship between Islamists in Pakistan and Afghanistan.

No one can seek to resolve problems in one country without examining developments in the other. It would seem that this more holistic understanding of the conflict system existing in the region has permeated the thinking of the new Obama administration, as seen in Richard Holbrooke's appointment as the US Special Envoy to Afghanistan and Pakistan. In a trip in April 2009 to the region, Holbrooke also visited India, which suggests that the US understands that India, too, has a vested interest in the stability of both Afghanistan and Pakistan. ${ }^{31}$

\section{Conclusion}

There is still a chance for the international community to bring durable, lasting peace to Afghanistan but it is guaranteed to take a long time. In order for the previous proposals to succeed, it is critical that all actors agree to reassess their individual and collective roles and strategies. The underlying theme of the foregoing policy recommendations is the critical need to reassess policy approaches to Afghanistan in a coherent and collective manner. This collective approach must also include the close engagement of the Afghan people to renew their trust and belief in international efforts. The Taliban are running a highly competitive propaganda campaign and it is in the interest of all international donors to develop ways of communicating their goals and plans to the local Afghan population. The most significant obstacle facing international efforts in Afghanistan is not the growing strength of a militant Taliban, but rather the international community's ignorance of Afghanistan's people - its languages, its cultures and its tribal customs. If 'enduring freedom' is to be achieved, we must abandon our conventional approaches to conflict resolution, think more dynamically and consider the real objective: bringing real and lasting peace to the Afghan people.

\section{Notes on contributors}

Allison M Coady is the Programme Manager at the Denis Hurley Peace Institute (DHPI), an associate body of the Southern African Catholic Bishops Conference. She has a BA Honors in History and a minor in Political Science from Mount Allison University in New Brunswick, Canada in 2006. Her research interests include South African foreign policy toward Zimbabwe, civil society, democracy, constitutional development, conflict resolution, African and Middle Eastern politics, and European and North American modern history. She has worked as a Researcher and a Liaison Officer for the International Centre for Human Rights and Democratic Development (Rights \& Democracy) from 2006-2008, in both Montreal, Canada and in Pretoria, South Africa.

Hussein Solomon lectures in the Department of Political Sciences at the University of Pretoria, South Africa and is also Director of the Centre for International Political Studies. He holds a D. Litt et Phil (Political Science) from the University of South Africa. He sits on the International Steering Committee of the Toda Institute for Global Peace and Policy Research in Hawaii and serves as a member of the Executive Committee of Global Action to Prevent War. Currently he is a Visiting Fellow in the Mackinder Programme for the Study of Long-Wave Events at the London School of Economics. 


\section{Notes}

1. United Nations, 2001, p. 1.

2. Human Rights Watch, 2002.

3. Ibid.

4. 'Warlords, Taliban and drugs fuel violence', 2008.

5. 'Taliban propaganda: Winning the war of words', 2008, p. 8.

6. Ibid.

7. Ibid, p. 8 .

8. Rashid, 2001, p. 19.

9. 'Taliban propaganda: Winning the war of words', 2008, p. 8.

10. 'Who are the Taleban?', 2008.

11. Waldman, 2001.

12. 'Who are the Taleban?', 2008.

13. Report on the Taliban's War Against Women, 2001.

14. Ibid.

15. Ibid.

16. UNDP, 2007, p. 59

17. Loyn, 2008.

18. 'Taliban threaten suicide bombings in Pakistan', 2008.

19. 'Taliban propaganda: Winning the war of words', p. 9.

20. Ibid, p. 12.

21. Ibid.

22. Rondeaux, 2008, p. A15.

23. Ibid.

24. Ibid.

25. Ibid.

26. UNDP, 2007, p. 59.

27. Schneider, 2008.

28. UNDP, 2007, p. 59.

29. Ibid, p. 60.

30. Ibid, p. 61.

31. Klein, 2009.

\section{References}

'Afghanistan's Bonn Agreement one year later: A catalog of missed opportunities', Human Rights Watch, 5 December 2002.

Klein J, 'The diplomacy surge', Time, 20 April 2009, pp. 18-19.

Loyn D, 'Why the Afghan Taleban feel confident', BBC News, 1 February 2008, http://news.bbc.co.uk/2/hi/south_asia/7222194.stm (date accessed 31 July 2008).

Rashid A, Taliban: Militant Islam, Oil and Fundamentalism in Central Asia. New Haven: Yale University Press, 2001.

Report on the Taliban's War Against Women. Washington, DC: US Department of State Bureau of Democracy, Human Rights and Labor, 2001, http://www.state.gov/g/drl/rls/6185.htm (date accessed 4 August 2008).

Rondeaux C, 'U.S., Afghan troops leave combat outpost after deadly clash', Washington Post Foreign Service, 17 July 2008, p. A15.

Schneider M, 'Strategic incoherence and Taliban resurgence in Afghanistan', The Huffington Post, 20 May 2008, http://www.huffingtonpost.com/mark-schneider/strategic-incoherence-and_b_102725. html (date accessed 7 August 2008).

'Taliban propaganda: Winning the war of words?', International Crisis Group, 24 July 2008, www.crisisgroup.org/home/index.cfm?id=5589\&CFID=62423416\&CFTOKEN $=43792180$ (date accessed 7 August 2008).

'Taliban threaten suicide bombings in Pakistan', The State, www.thefreelibrary.com/Taliban+thre aten+suicide+bombings+in+Pakistan-901611597871 (date accessed 8 August 2008).

United Nations Development Programme (UNDP), Center for Policy and Human Development, Afghanistan Human Development Report 2007. New York: UNDP, 2007. 
Waldman A, 'A nation challenged: The law; no TV, no chess, no kites: Taliban's code, from A to Z', The New York Times, 22 November 2001, http://query.nytimes.com/gst/fullpage.html?res = 9501E5DE143AF931A15752C1A9679C8B63 (date accessed 4 August 2008).

'Warlords, Taliban and drugs fuel violence', Reuters, 2008, http://www.alertnet.org/db/crisisprofiles/ AF_REC.htm? $=$ in_detail (date accessed 6 August 2008).

'Who are the Taleban?', BBC News, 7 July 2008, http://news.bbc.co.uk/2/hi/south_asia/1549285.stm (date accessed 31 July 2008). 